\title{
A HEIGHT-DIAMETER MODEL FOR BRUTIAN PINE (PINUS BRUTIA TEN.) PLANTATIONS IN SOUTHWESTERN TURKEY
}

\author{
ÇATAL, Y. ${ }^{*}$ - CARUS, S. \\ Department of Forest Engineering, Faculty of Forestry, Süleyman Demirel University \\ Isparta, Turkey \\ *Corresponding author \\ e-mail: yilmazcatal@sdu.edu.tr \\ (Received $13^{\text {th }}$ Nov 2017; accepted $20^{\text {th }}$ Feb 2018)
}

\begin{abstract}
In this study, models for the tree total height have been developed for brutian pine (Pinus brutia Ten.) stands in southwestern Turkey. For this purpose, 52 sample plots were measured. A total of 36 models that estimate the relationship between height and diameter in terms of stand variables (i.e. basal area, quadratic mean diameter, maximum diameter, dominant diameter, dominant height, arithmetic mean height, age, number of trees per hectare and site index), were fitted to correspond to 766 trees for non-linear regression procedures. Comparison of the models was carried out by using mean absolute error (MAE), maximum absolute error (MaxAE), root mean square error (RMSE), correlation coefficients (R), mean error (Bias) and the Akaike's information criterion (AIC). The most successful model among the 36 height-diameter models used was the Cox $\mathrm{II}_{\mathrm{a}}$ model. This model was followed by Cox $\mathrm{II}_{\mathrm{b}}$ and Sharma \& Parton, respectively. As a result, the suggested model improves the accuracy of height prediction, ensures compatibility among the various estimates in a growth and yield model, and maintains projections within reasonable biological limits. Examples of applications of the selected generalized diameter-height models to the forest management are presented, namely how to use it to complete missing information from forest inventory and also showing how such an equation can be incorporated in a stand-level decision support system that aims to optimize the forest management for the maximization of wood volume production in southwestern Turkey brutian pine stands.
\end{abstract}

Keywords: generalized height-diameter models, stand age, stand density, site index

\section{Introduction}

All models are an abstraction of reality that attempt to conceptualize key relationships of a system. Models can be both quantitative and conceptual in nature, but all models are integrators of multiple fields of knowledge. Forest growth and yield models are no different (Weiskittel et al., 2011). Total height is less frequently used in the development of forest models than diameter, as it is difficult and costly to measure, and consequently inaccurate measurements are often made (Sharma and Parton, 2007). When actual height measurements are not available, height-diameter functions can also be used to indirectly predict height growth (Larsen and Hann, 1987).

The relationship between tree height and diameter is one of the most important elements of forest structure. Many growth and yield models require height and diameter as basic input variables, with all or part of the tree height predicted from measured diameters (Wykoff et al., 1982; Huang et al., 2000).

Height-diameter relationships are applied to even-aged stands and can be fitted to linear functions, such as second-order polynomial equations, or more usually, to nonlinear models (Colbert et al., 2002; Soares and Tomé, 2002; Castedo Dorado et al., 2006; Lootens et al., 2007). Model selecting a functional form for the height-diameter relationship, the following mathematical properties should be considered: (i) monotonic ascent, (ii) inflection point and (iii) horizontal asymptote (Lei and Parresol, 
2001). The number of parameters and their biological interpretation (e.g., asymptote, maximum or minimum growth rate) and satisfactory predictions of the heightdiameter relationships are also important features (Peng, 1999).

A generalized height-diameter function estimates the specific relationship between individual tree heights and diameters using stand variables such as basal area per hectare, quadratic mean diameter, stands age, number of trees. The reason for using them is to avoid having to establish individual height-diameter relationships for every stand (Curtis, 1967). A wide variety of both local and generalized height-diameter models are available in the forestry literature (Huang et al., 2000; Soares and Tomé, 2002; López Sánchez et al., 2003; Temesgen and Gadow, 2004). Because of different geographical conditions in Turkey, the variety of tree species, habitat and stand structures is very high. However, equations reveal height-diameter relations for a limited number of different tree species and natural stands have been developed in Turkey (Sönmez, 2008; Mısır, 2010; Çatal, 2012; Diamantopoulou and Özçelik, 2012; Özçelik and Çapar, 2014). Generalized diameter-height models should be created to deal with pure brutian pine (Pinus brutia Ten.) plantation which was established 50 years ago. However, height-diameter models for brutian pine plantations are not yet available in Turkey.

Ecologically and economically, it is one of the most important forest tree species in Turkey. Brutian pine accounts for $25.1 \%$ of Turkey's total forest area, where it covers 5.6 million hectares. The species is considered fast growing and drought-tolerant with desirable wood characteristics. It is also widely used in reforestation and afforestation in Turkey (Anonymous, 2015). The aim of this study is to find an equation from selected generalized height-diameter models that could be used to predict the diameter-height relationship in artificial brutian pine stands in southwestern Turkey, by considering a number of stand variables (e.g., dominant diameter, dominant height, age, density, site index, etc.). The models divided into three groups and compare the models in three groups. These groups were the following i) diameter measurements, knowledge of stand age and number of trees per hectare, ii) measurements of diameter and height of sample trees, and ii) addition of measurements of stand age to the second group.

\section{Materials and methods}

\section{Data used}

Brutian pine is a characteristic species of the eastern Mediterranean and commonly found in fire-related ecosystems of the eastern Mediterranean region. It usually grows in pure stands and is valuable for its timber products as well as for soil stabilization and wildlife habitats. In Turkey, brutian pine forms extensive forests, especially in regions where the Mediterranean climate prevails.

This research was carried out in the region of southwestern Turkey, located, $50 \mathrm{~km}$ to the east of Burdur (Fig. 1).

The 650 ha study area is situated at $37^{\circ} 38^{\prime} 06^{\prime \prime} \mathrm{N}$ lat., $30^{\circ} 32^{\prime} 37^{\prime}$ ' E long., average slope $15^{\circ}$, predominantly north-facing aspect, $1,150 \mathrm{~m}$ asl. The soil is generally shallow or medium-deep, and stony, with a predominantly clay texture. Brutian pine plantations were established in 1974 using a spacing of $3 \times 2 \mathrm{~m}$.

Tree heights and diameters were measured in 52 sample plots established in pure and, even-aged artificial brutian pine stands in southwestern Turkey region. The plots were square or rectangular with areas varying between 400 and $1600 \mathrm{~m}^{2}$. The number of 
trees per plot ranges between 32 and 115 depending on stocking. The sample plots were installed in order to provide the greatest variety of combinations of stand age, stand density degree and site index. In each sample plot, diameters at breast height of all trees were crosswise measured, using Haglöf calipers, to the nearest millimetre. Heights were measured using a Silva hypsometer to the nearest $0.1 \mathrm{~m}$. In each sample plot 10-20 sample trees with different diameters and heights were chosen. Sample trees should not have any crown or stem damage.

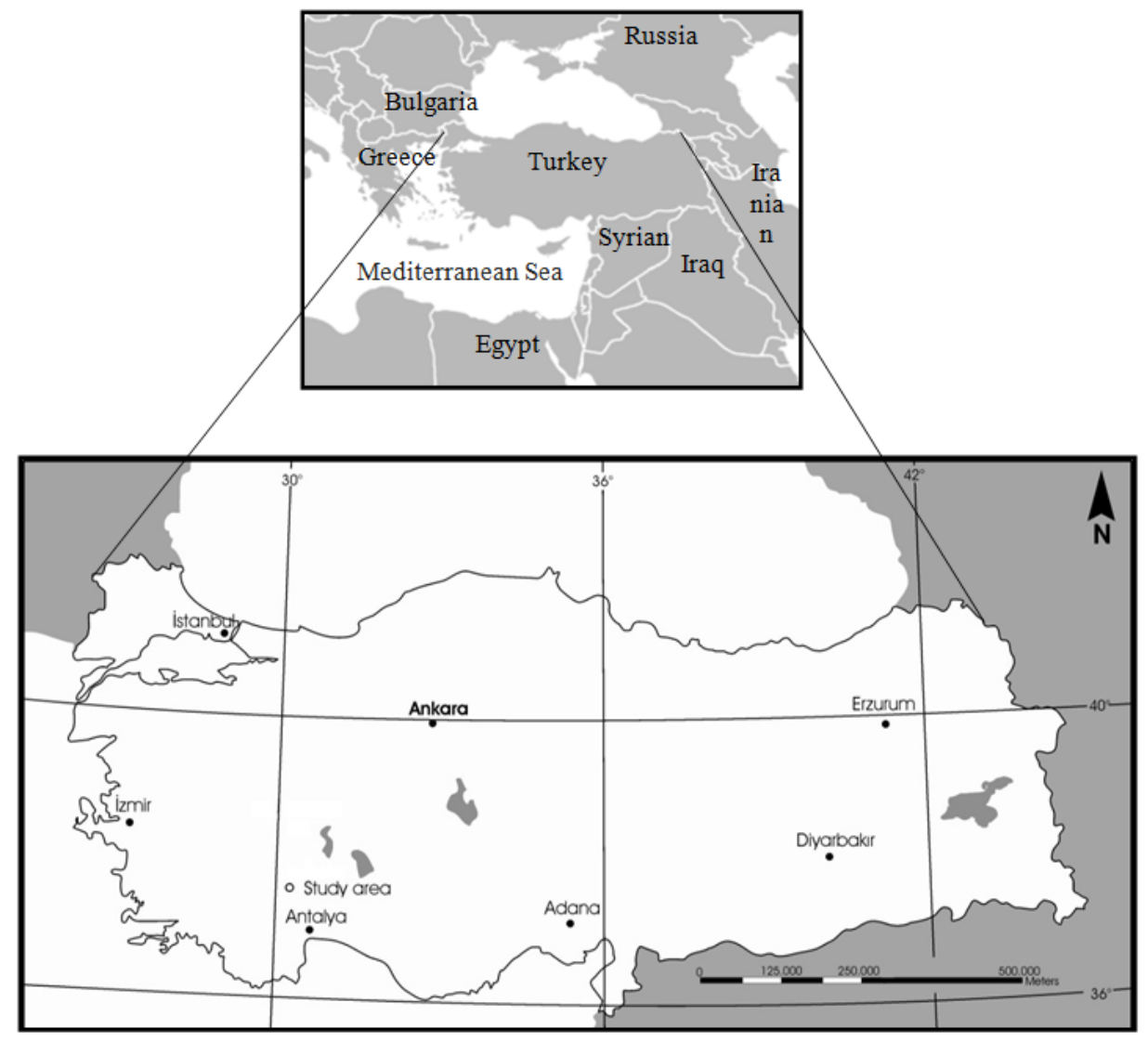

Figure 1. Location of sample plots in Turkey

In addition the following stand variables were calculated based on the data collected in the plots: stand basal area, quadratic mean diameter, maximum diameter, dominant diameter, dominant height, stand mean height, stand age (it was calculated from the year of planting), stand density and site index, defined as stand dominant height at 30 years of age and determined from the site index curves available for this species in the region (Usta, 1991).

\section{Models analysed}

A large number of generalized height-diameter models have been discussed in the forestry literature, many of which been developed for modelling the relationship between tree height and diameter at breast height by additional stand and site variables. In the present study, we have considered the most commonly used 36 generalized height-diameter equations (Table 1). 
Table 1. Generalized height-diameter models evaluated

\begin{tabular}{|c|c|c|}
\hline The first group model (Group model 1) & Author (s) & Model \\
\hline$h=1 \mathrm{O}^{\left(a_{0}+a_{1} \frac{1}{d}+a_{2} \frac{1}{t}+a_{3} \frac{1}{d_{g} t}\right)}$ & Curtis (1967) & 1 \\
\hline $\boldsymbol{h}=e^{\left(a_{0}+a_{1} \ln d_{g}+a_{2} \ln N+a_{3} \sqrt{d}\right)}$ & Cox I (1994) & 2 \\
\hline$h=1.30+10^{\left(a_{0}+a_{1} \frac{1}{d}+a_{2} \frac{1}{\sqrt{t}}+a_{3} \frac{1}{d \sqrt{t}}+a_{4} \frac{\log N}{\sqrt{t}}\right)}$ & \begin{tabular}{|c|} 
Clutter and Allison \\
$(1974)$
\end{tabular} & 3 \\
\hline The second group model (Group model 2) & Author (s) & Model \\
\hline$h=1.30+\left[a_{0}\left(\frac{1}{d}-\frac{1}{D_{0}}\right)+\left(\frac{1}{H_{0}-1.3}\right)^{1 / 3}\right]^{-3}$ & Mǿnnes (1982) & 4 \\
\hline$h=1.30+\left(H_{\mathrm{o}}-1.3\right)\left(\frac{d}{D_{0}}\right)^{a_{0}}$ & $\begin{array}{l}\text { Canadas et al. I } \\
\text { (1999) }\end{array}$ & 5 \\
\hline$h=1.30+\frac{d}{\frac{D_{0}}{H_{0}-1.3}+a_{0}\left(D_{0}-d\right)}$ & $\begin{array}{l}\text { Canadas et al. II } \\
\text { (1999) }\end{array}$ & 6 \\
\hline$h=1.30+\left(H_{0}-1.3\right) \frac{1-e^{a_{0} d}}{1-e^{a_{0} D_{0}}}$ & $\begin{array}{c}\text { Canadas et al. III } \\
\text { (1999) }\end{array}$ & 7 \\
\hline$h=1.30+\left[a_{0}\left(\frac{1}{d}-\frac{1}{D_{0}}\right)+\left(\frac{1}{H_{0}-1.3}\right)^{1 / 2}\right]^{-2}$ & $\begin{array}{c}\text { Canadas et al. IV } \\
\text { (1999) }\end{array}$ & 8 \\
\hline$h=1.30+\left(H_{0}-1.3\right) e^{a_{0}\left(1-\frac{d_{g}}{d}\right)+a_{1}\left(\frac{1}{d_{g}}-\frac{1}{d}\right)}$ & Gaffrey (1988) & 9 \\
\hline$h=1.30+\left(H_{0}-1.3\right)\left[1+a_{0}\left(H_{0}-1.3\right)\left(\frac{1}{d}-\frac{1}{D_{0}}\right)\right]^{-1}$ & Prodan (1968) & 10 \\
\hline$h=1.30+H_{0}\left(1+a_{0}+a_{1} H_{0}+a_{2} d_{g}\right) e^{a_{3} H_{0}}\left(1-e^{a_{4} \frac{d}{H_{0}}}\right)$ & $\begin{array}{l}\text { Soares and Tome } \\
\text { (2002) }\end{array}$ & 11 \\
\hline$h=1.30+\left(H_{m}-1.3\right) e^{a_{0}\left(1-\frac{d}{d_{g}}\right)} e^{a_{1}\left(\frac{d}{d_{g}}-\frac{1}{d}\right)}$ & $\begin{array}{l}\text { Sloboda et al. } \\
\quad(1993)\end{array}$ & 12 \\
\hline$h=H_{0}\left(1+a_{0} e^{a_{1} H_{0}}\right)\left(1-e^{\frac{-a_{2} d}{H_{0}}}\right)$ & $\begin{array}{l}\text { Harrison et al. } \\
\quad(1986)\end{array}$ & 13 \\
\hline$h=1.30+\frac{a_{0} H_{0}^{a_{1}}\left(H_{0}-1.3\right)}{\left(\left|\frac{D_{0}-d}{d}\right|\right)^{a_{2}}}$ & $\begin{array}{c}\text { Castedo Dorado et } \\
\text { al. (2001) }\end{array}$ & 14 \\
\hline$h=a_{0} H_{0}\left(1-e^{\frac{-a_{1} d}{d_{g}}}\right)^{a_{2}}$ & $\begin{array}{l}\text { Pienaar et al.a } \\
\quad(1990)\end{array}$ & 15 \\
\hline$h=a_{0} H_{0}\left(1-e^{\frac{-a_{1} d}{D_{0}}}\right)^{a_{2}}$ & $\begin{array}{l}\text { Pienaar et al.b } \\
\quad(1990)\end{array}$ & 16 \\
\hline$h=1.30+\left(H_{m}-1.3\right) e^{a_{0}\left(1-\frac{d}{D_{0}}\right)} e^{a_{1}\left(\frac{d}{D_{0}}-\frac{1}{d}\right)}$ & $\begin{array}{l}\text { Sloboda et al. } \\
\quad(1993)\end{array}$ & 17 \\
\hline$h=1.30+a_{0} H_{0}^{a_{1}} d^{a_{2} H_{0}^{a_{3}}}$ & $\begin{array}{l}\text { Hui and Gadow } \\
\text { (1993) }\end{array}$ & 18 \\
\hline
\end{tabular}




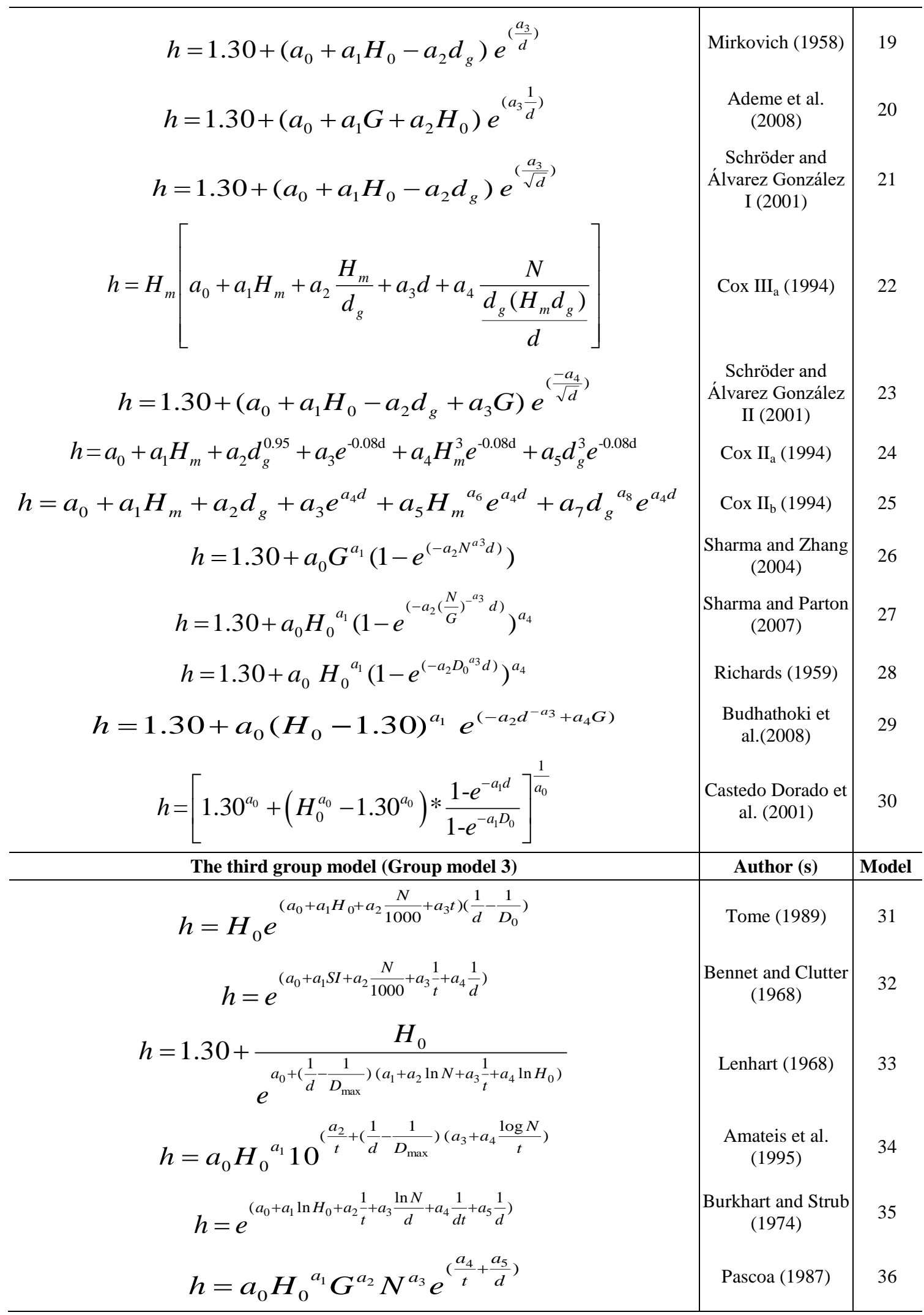

The terminology used in the up models is as follows: $\mathrm{d}=$ diameter at breast height over bark $(\mathrm{cm}), \mathrm{t}=$ age of stand, $\mathrm{d}_{\mathrm{g}}=$ quadratic mean diameter of stand $(\mathrm{cm}), \mathrm{G}=$ basal area of stand $\left(\mathrm{m}^{2} / \mathrm{ha}\right), \mathrm{D}_{\max }=$ maximum diameter of stand $(\mathrm{cm}), \mathrm{D}_{\mathrm{o}}=$ dominant diameter of stand $(\mathrm{cm}), \mathrm{H}_{\mathrm{m}}=$ mean height of stand $(\mathrm{m}), \mathrm{H}_{\mathrm{o}}=$ dominant height of stand $(\mathrm{m}), \mathrm{N}$ $=$ number of trees in stand $($ stems $/$ ha $), \mathrm{SI}=$ site index $(\mathrm{m}), \log =$ common logarithm (base 10$), \ln =$ natural logarithm (base e $=2,718), a_{0}, a_{1} \ldots=$ regression coefficients 
The models were classified in three groups according to the sampling effort (Sanchez et al., 2003). These groups; i) low sampling effort models; including measurements of diameter and knowledge of stand age, ii) medium sampling effort models, including measurements of diameter and heights of sample tree, iii) high sampling effort models, including knowledge or measurements of stand age as well.

\section{Statistical analysis}

In this study the models described above are non-linear; therefore model fitting was carried out with non-linear regression (NLIN) procedure of SPSS statistical analysis software package. The initial values of parameters were obtained by starting the iterative procedure also used by other authors in similar studies (Castedo Dorado et al., 2006; Özçelik and Çapar, 2014; Ahmadi et al., 2016).

Comparison of estimation of models was based on graphical and numerical analysis of residuals and six goodness of fit statistics: mean absolute error (MAE), which expresses the average of absolute errors between forecast and actual value; maximum absolute error (MaxAE), which maximum absolute value for prediction values; root mean square error (RMSE), which analyses the precision of estimations; correlation coefficients $(\mathrm{R})$, which reflect the total variability that is explained by the model considering the total number of parameters to be estimated; mean error (Bias), which average error for estimated values, and the Akaike's information criterion (AIC), which is an index that is used to select the best model. These evaluation statistics are defined as (Eqs. 1-6):

Mean absolute error:

$$
M A E=\frac{\sum_{i=1}^{n}\left|h_{i}-\hat{h}_{i}\right|}{n}
$$

Maximum absolute error:

$$
\operatorname{MaxAE}=\operatorname{Max}\left(\left|h_{i}-\hat{h}_{i}\right|\right)
$$

Root mean square error:

$$
R M S E=\sqrt{\frac{\sum_{i=1}^{n}\left(h_{i}-\hat{h}_{i}\right)^{2}}{n-k}}
$$

Correlation coefficients:

$$
R=\frac{\sum_{i=1}^{n}\left(h_{i}-\bar{h}_{i}\right) *\left(\hat{h}_{i}-\bar{h}_{i}\right)}{\left.\sqrt{\sum_{i=1}^{n}\left(h_{i}-\bar{h}_{i}\right.}\right)^{2} * \sqrt{\sum_{i=1}^{n}\left(\hat{h}_{i}-\bar{h}_{i}\right)^{2}}}
$$


Mean error:

$$
\text { Bias }=\frac{\sum_{i=1}^{n}\left(h_{i}-\hat{h}_{i}\right)}{n}
$$

Akaike's information criterion:

$$
A I C=n * \ln (R M S E)+2 * p
$$

where $h_{i}=$ observed height, $\hat{h}_{i}$ redicted height, $\bar{h}_{i}$ ean of observed heights, $n=$ number of observations in dataset and $k=$ number of estimated parameters.

\section{Results and discussion}

\section{Data summary}

Approximately $80 \%$ (42 sample plots) of sample plots data were used to develop model and remaining 20\% (10 sample plots) were used to test developed models. The dataset for test of developed models was intended to obtain a measure of the adequacy of the calibration from different sampling stands. Since the data set is large enough, this proportions used is unlikely to reduce the precision of the parameter estimates compared with those obtained with the model built from the entire dataset in forestry research or data mining (Soares and Tomé, 2002; Castedo Dorado et al., 2006). The mean, minimum and maximum values and standard deviations of stand variables are shown in Table 2.

Table 2. Characteristics of the fitting and evaluation data set

\begin{tabular}{c|c|c|c|c|c|c|c|c}
\hline \multirow{2}{*}{ Variables } & \multicolumn{3}{|c|}{ Fitting data set $(\mathbf{n}=\mathbf{7 9 4})$} & \multicolumn{3}{c}{ Evaluation data set (n = 241) } \\
\cline { 2 - 8 } & Mean & Minimum & Maximum & $\begin{array}{c}\text { Standard } \\
\text { deviation }\end{array}$ & Mean & Minimum & Maximum & $\begin{array}{l}\text { Standard } \\
\text { deviation }\end{array}$ \\
\hline $\mathrm{d}(\mathrm{cm})$ & 21.2 & 12.1 & 34.7 & 3.2 & 21.5 & 11.0 & 33.5 & 3.6 \\
$\mathrm{~h}(\mathrm{~m})$ & 9.9 & 5.9 & 19.0 & 1.8 & 10.5 & 5.5 & 16.0 & 2.0 \\
$\mathrm{~A}(\mathrm{yr})$ & 36 & 32 & 41 & 2.5 & 37 & 32 & 41 & 2.8 \\
$\mathrm{dg}(\mathrm{cm})$ & 20.9 & 18.1 & 25.3 & 1.6 & 21.3 & 18.0 & 26.3 & 2.0 \\
$\mathrm{G}\left(\mathrm{m}^{2} \mathrm{ha}^{-1}\right)$ & 27.6 & 17.1 & 42.5 & 4.6 & 28.7 & 20.6 & 46.4 & 6.0 \\
$\mathrm{~N}\left(\mathrm{trees} \mathrm{ha}^{-1}\right)$ & 814 & 448 & 1136 & 136 & 805 & 624 & 1104 & 140.8 \\
$\mathrm{H}_{\mathrm{o}}(\mathrm{m})$ & 10.6 & 8.0 & 17.2 & 1.6 & 11.6 & 9.4 & 15.3 & 2.0 \\
$\mathrm{D}_{\mathrm{o}}(\mathrm{cm})$ & 25.1 & 21.9 & 30.9 & 1.9 & 25.6 & 21.0 & 31.2 & 2.4 \\
$\mathrm{D}_{\text {max }}(\mathrm{cm})$ & 27.3 & 23.7 & 34.7 & 2.3 & 27.3 & 22.3 & 34.6 & 2.9 \\
$\mathrm{H}_{\mathrm{m}}(\mathrm{m})$ & 9.8 & 7.5 & 15.3 & 1.4 & 10.5 & 8.4 & 13.5 & 1.5 \\
$\mathrm{SI}_{(\mathrm{m})}$ & 9.5 & 7.5 & 15.7 & 1.4 & 10.3 & 8.9 & 13.6 & 1.7 \\
\hline
\end{tabular}

The terminology used in the table is as follows: $\mathrm{d}=$ diameter at breast height over bark $(\mathrm{cm}), \mathrm{A}=$ age of stand $(\mathrm{yr}), \mathrm{d}_{\mathrm{g}}=$ quadratic mean diameter of stand $(\mathrm{cm}), \mathrm{G}=$ basal area of stand $\left(\mathrm{m}^{2} / \mathrm{ha}\right), \mathrm{D}_{\max }=$ maximum diameter of stand $(\mathrm{cm}), \mathrm{D}_{\mathrm{o}}=$ dominant diameter of stand $(\mathrm{cm}), \mathrm{h}=$ height of trees $(\mathrm{m}), \mathrm{H}_{\mathrm{m}}=$ mean height of stand $(\mathrm{m}), \mathrm{H}_{\mathrm{o}}=$ dominant height of stand $(\mathrm{m}), \mathrm{N}=$ number of trees in stand (trees/ha), SI $=$ site index $(m), n=$ number of sampling trees 
Relationship between height and diameter for data fitting model, validation model and all data are shown in Figure 2.
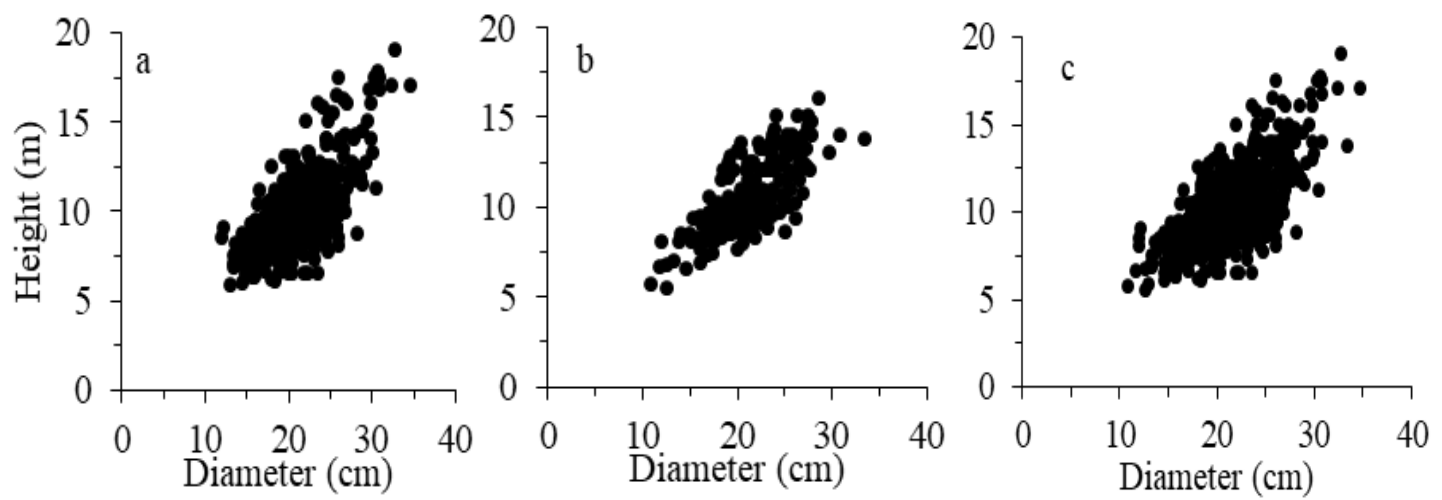

Figure 2. Relationship between diameter and height for data fitting model (a), data validation model (b) and all data (c)

\section{Model fitting}

Modelling for biological systems sense is an important tool. Modelling is the process of defining a system's change with equations (Weiskittel et al., 2011). It is therefore important to accurately determine the components of system during modelling and to select the correct equation to describe this system. In our study, it was tried to explain the change of tree height in relation with diameter at breast height according to the regression models in southwestern Turkey. The parameter values for all equations are included in Table 3.

The model parameters for all the tested models were found to be significant at the significance level of 0.001 . In order to find out which model was more successful in explaining height-diameter relation, a ranking was made for all models according to the specified criteria and the results were shown below. In this ranking method, numerical values were given starting from the smallest MAE, MaxAE, RMSE, ME, AIC ones and for the $\mathrm{R}$ value, starting with the highest one. When the ranking values obtained for each model were collected, the model with the smallest value was considered as the best one (Table 4).

In this study were found to be similar with the model results of the previous studies (Sanchez et al., 2003; Castedo Dorado et al., 2006). In terms of group averages, the third group of equations was found to be more successful. But, the most successful model among the 36 height-diameter models used was the Cox $\mathrm{II}_{\mathrm{a}}$ model, followed by Cox $\mathrm{II}_{\mathrm{b}}$ and Sharma and Parton, respectively. Curtis, Gaffrey \& Sharma and Zhang models have been not suitable for this region.

The results of fitting and cross-validation for the models of group 1 were the poorest. In this respect, a number of studies showed that adding stand variables to the heightdiameter equation and using the generalized height-diameter models increased the precision (Sharma and Parton, 2007; Krisnawati et al., 2010; Temesgen et al., 2014). These stand variables mentioned in the literature are dominant height, stand basal area, maximum diameter, stand age, number of trees per hectare, stand density. The statistics and coefficients according to the studied model were found to be similar to the results of the previous model studies (Larsen and Hann, 1987; Colbert et al., 2002). The inclusion 
of basal area and $\mathrm{d}_{\mathrm{g}}$ into the base height-diameter function increased the accuracy of prediction (Temesgen and Gadow, 2004).

Table 3. Parameters of non-linear regression models

\begin{tabular}{|c|c|c|c|c|c|c|c|c|c|}
\hline \multirow{2}{*}{ Model no } & \multicolumn{9}{|c|}{ Parameters } \\
\hline & $\mathbf{a}_{0}$ & $\mathbf{a}_{1}$ & $\mathbf{a}_{2}$ & $\mathbf{a}_{3}$ & $\mathbf{a}_{4}$ & $a_{5}$ & $a_{6}$ & $\mathbf{a}_{7}$ & $\mathbf{a}_{8}$ \\
\hline 1 & 1.716443 & -5.306083 & -15.181403 & -0.022643 & - & - & - & - & - \\
\hline 2 & -4.159129 & 0.960891 & 0.338363 & 0.275196 & - & - & - & - & - \\
\hline 3 & 3.834179 & -41.321130 & -19.480656 & 207.082437 & 1.393833 & - & - & - & - \\
\hline 4 & 1.846925 & - & - & - & - & - & - & - & - \\
\hline 5 & 0.526950 & - & - & - & - & - & - & - & - \\
\hline 6 & -0.048474 & - & - & - & - & - & - & - & - \\
\hline 7 & -0.053122 & - & - & - & - & - & - & - & - \\
\hline 8 & 1.924790 & - & - & - & - & - & - & - & - \\
\hline 9 & -0.005893 & 10.695102 & - & - & - & - & - & - & - \\
\hline 10 & 0.283957 & - & - & - & - & - & - & - & - \\
\hline 11 & -353.995785 & 7.157280 & 5.451819 & 0.129807 & 0.000621 & - & - & - & - \\
\hline 12 & -1.851475 & -0.989978 & - & - & - & - & - & - & - \\
\hline 13 & 0.106958 & 1.500000 & 0.468510 & - & - & - & - & - & - \\
\hline 14 & 0.966326 & -0.051939 & 0.037236 & - & - & - & - & - & - \\
\hline 15 & 1.165160 & 2.226022 & 1.982192 & - & - & - & - & - & - \\
\hline 16 & 1.298927 & 1.668149 & 1.167713 & - & - & - & - & - & - \\
\hline 17 & -22.383484 & -6.374520 & - & - & - & - & - & - & - \\
\hline 18 & 6.314068 & -0.311706 & 0.424369 & 0.074948 & - & - & - & - & - \\
\hline 19 & 7.913832 & 1.473407 & 0.358958 & -13.137764 & - & - & - & - & - \\
\hline 20 & 2.261735 & -0.016805 & 1.239617 & -11.641012 & - & - & - & - & - \\
\hline 21 & 15.323304 & 2.724760 & 0.677738 & -5.761236 & - & - & - & - & - \\
\hline 22 & 0.468122 & -0.045892 & 0.929943 & 0.025909 & 0.471646 & - & - & - & - \\
\hline 23 & 15.386189 & 2.750300 & 0.674077 & -0.015238 & 5.759656 & - & - & - & - \\
\hline 24 & 1.651100 & 1.043897 & 0.073152 & -5.834839 & -0.000625 & -0.001224 & - & - & - \\
\hline 25 & -122.918442 & 0.975019 & -0.790733 & 121.929973 & 0.001889 & $5 \times 10^{-9}$ & 6.477289 & 0.813999 & 0.894380 \\
\hline 26 & 3.178352 & 0.562636 & 0.115088 & -0.223862 & & - & - & - & - \\
\hline 27 & 1.122581 & 0.988632 & 0.026346 & -0.374752 & 1.972110 & - & - & - & - \\
\hline 28 & 1.072885 & 1.031935 & 1.141993 & -0.850653 & 1.487636 & - & - & - & - \\
\hline 29 & 0.016350 & 0.770381 & -3.156851 & -0.121544 & -0.001077 & - & - & - & - \\
\hline 30 & -0.000691 & 0.114182 & - & - & - & - & - & - & - \\
\hline 31 & -2.608873 & -0.804187 & 0.196157 & 0.037243 & & - & - & - & - \\
\hline 32 & 2.494066 & 0.060584 & 0.101072 & -13.008971 & -10.368192 & - & - & - & - \\
\hline 33 & 0.073700 & 33.485427 & -3.034925 & -11.024664 & -0.154562 & - & - & - & - \\
\hline 34 & 1.224536 & 0.926236 & 0.319181 & -7.179243 & 29.976501 & - & - & - & - \\
\hline 35 & 0.542895 & 0.804716 & 13.096415 & 1.259923 & -162.752624 & -14.715665 & - & - & - \\
\hline 36 & 1.150484 & 0.893337 & -0.206565 & 0.188713 & 0.415724 & -11.460517 & - & - & - \\
\hline
\end{tabular}

$\mathrm{a}_{0}, \mathrm{a}_{1} \ldots=$ regression coefficients

The values of statistics of the models included in group model 2 show that the second modification of $\operatorname{Cox} \mathrm{II}_{\mathrm{a}}$ is the equation that most accurately estimates height. The best equation was found in the second group because of a low variation in stand age. When the stand age variation was high, the group model 2 was more successful than group model 3. 
The models of Cox $\mathrm{II}_{\mathrm{b}}$ and Sharma \& Parton also fit well to the data in Table 4. The advantage of these models was that they were functions of simple equation, although the bias and MSE were slightly higher than those of the modified versions of the Cox $\mathrm{II}_{\mathrm{a}}$ model.

Table 4. Performance criteria for generalized height-diameter models for the fitting data

\begin{tabular}{|c|c|c|c|c|c|c|c|}
\hline \multirow{2}{*}{$\begin{array}{c}\text { Model } \\
\text { no }\end{array}$} & \multicolumn{7}{|c|}{ Performance criteria } \\
\hline & MAE & $\operatorname{MaxAE}$ & RMSE & $\mathbf{R}$ & ME & AIC & Rank \\
\hline 1 & $1.23352(36)$ & $70653(35)$ & $1.54613(36)$ & $0.51256(36)$ & $-0.91648(36)$ & $353.990(36)$ & 36 \\
\hline 2 & 0.90645 & $3.97724(33)$ & 1.15783 & $0.76586(33)$ & $0.00338(16)$ & $124.359(33)$ & 30 \\
\hline 3 & $0.86868(32)$ & $5.37752(36)$ & $1.16102(34)$ & $0.76472(34)$ & $0.00182(14)$ & $128.543(35)$ & 32 \\
\hline 4 & $0.61337(17)$ & $2.90029(19)$ & $0.78395(15)$ & $0.89985(15)$ & $0.08043(29)$ & $-191.270(13)$ & 20 \\
\hline 5 & $0.61940(21)$ & $2.94987(24)$ & $0.79151(19)$ & $0.89780(20)$ & $0.09082(35)$ & $-183.647(17)$ & 24 \\
\hline 6 & $0.63727(26)$ & $2.98865(26)$ & $0.81630(25)$ & $0.89090(25)$ & $0.15062(31)$ & $-159.161(24)$ & 27 \\
\hline 7 & $0.61708(19)$ & $2.90005(18)$ & 0.78865 & $0.89858(17)$ & $0.08608(30)$ & $-186.522(15)$ & 21 \\
\hline 8 & $0.61260(15)$ & $2.91290(22)$ & $0.78312(14)$ & $0.90007(14)$ & $0.07878(28)$ & $-192.109(12)$ & 17 \\
\hline 9 & $0.89279(33)$ & $3.73911(30)$ & $1.11244(32)$ & $0.78572(32)$ & $-0.07513(34)$ & $88.605(32)$ & 35 \\
\hline 10 & $0.85097(31)$ & 3.96399 (32) & $1.09746(31)$ & $0.79191(31)$ & $-0.53040(33)$ & $75.841(31)$ & 33 \\
\hline 11 & $0.68984(28)$ & $3.03966(28)$ & $0.88701(28)$ & 0.87043 & $0.05039(25)$ & $-85.200(28)$ & 28 \\
\hline 12 & 0.56765 & $2.65307(9)$ & $0.71431(2)$ & $0.91773(3)$ & $0.05888(26)$ & $-263.132(2)$ & 6 \\
\hline 13 & $0.63052(23)$ & $2.79037(16)$ & $0.80420(22)$ & $0.89458(22)$ & $-0.00365(17)$ & $-167.018(22)$ & 23 \\
\hline 14 & 0.73644 & 3.66945 (29) & $0.94454(29)$ & $0.85117(29)$ & 0.00550 (19) & $-39.304(30)$ & 29 \\
\hline 15 & $0.61041(13)$ & $2.75054(12)$ & $0.78863(16)$ & $0.89886(16)$ & $0.02120(24)$ & $-182.542(18)$ & 14 \\
\hline 16 & $0.60687(11)$ & $2.93672(23)$ & $0.77907(11)$ & $0.90143(11)$ & $0.01516(23)$ & $-192.226(10)$ & 12 \\
\hline 17 & $0.73333(29)$ & $4.35856(34)$ & $0.94479(30)$ & 0.85088 & $0.44719(32)$ & $-41.093(29)$ & 31 \\
\hline 18 & $0.68532(27)$ & 2.88025 (17) & $0.88680(27)$ & $0.87032(28)$ & $-0.00723(20)$ & $-87.388(27)$ & 26 \\
\hline 19 & $0.59900(6)$ & $2.58431(5)$ & $0.77400(7)$ & $0.90290(7)$ & $0.00023(3)$ & $-195.410(5)$ & 4 \\
\hline 20 & $0.62974(22)$ & $2.69422(10)$ & $0.80497(23)$ & $0.89451(23)$ & $0.00021(1)$ & $-164.259(23)$ & 15 \\
\hline 21 & $0.59904(7)$ & $2.62233(8)$ & $0.77492(8)$ & $0.90266(9)$ & $-0.00045(6)$ & $-194.466(8)$ & 7 \\
\hline 22 & $0.57292(4)$ & 2.60799 (7) & $0.72224(4)$ & 0.91615 (4) & $0.00141(13)$ & $-248.366(3)$ & 5 \\
\hline 23 & $0.59916(8)$ & $2.60273(6)$ & $0.77526(9)$ & $0.90270(8)$ & $-0.00046(7)$ & $-192.118(11)$ & 8 \\
\hline 24 & $0.56047(1)$ & $2.36446(1)$ & $0.70628(1)$ & $0.92008(1)$ & $-0.00044(5)$ & $-264.108(1)$ & 1 \\
\hline 25 & $0.56484(2)$ & $2.49484(2)$ & $0.71598(3)$ & $0.91810(2)$ & $-0.00281(15)$ & $-247.278(4)$ & 2 \\
\hline 26 & $0.91127(35)$ & $3.89076(31)$ & $1.16327(35)$ & $0.76332(35)$ & $0.00788(21)$ & $128.081(34)$ & 34 \\
\hline 27 & $0.59885(5)$ & $2.55334(4)$ & $0.77289(5)$ & $0.70332(5)$ & $0.00037(4)$ & $-194.549(6)$ & 3 \\
\hline 28 & $0.60058(9)$ & $2.95984(25)$ & $0.77290(6)$ & $0.90332(6)$ & $-0.00022(2)$ & $-194.539(7)$ & 9 \\
\hline 29 & $0.63466(24)$ & $2.73507(11)$ & $0.80966(24)$ & $0.89335(24)$ & 0.00127 (11) & $-157.646(25)$ & 22 \\
\hline 30 & $0.60831(12)$ & $2.90991(21)$ & $0.78097(12)$ & $0.90079(12)$ & $0.01201(22)$ & $-192.292(9)$ & 11 \\
\hline 31 & $0.61129(14)$ & $2.90111(20)$ & $0.78283(13)$ & 0.90055 (13) & $0.06951(27)$ & $-186.403(16)$ & 16 \\
\hline 32 & $0.63609(25)$ & $3.01366(27)$ & $0.81981(26)$ & $0.89049(26)$ & $-0.00138(12)$ & $-147.754(26)$ & 25 \\
\hline 33 & $0.61363(18)$ & $2.78609(15)$ & $0.79100(18)$ & $0.89848(18)$ & $-0.00409(18)$ & $-176.159(19)$ & 19 \\
\hline 34 & $0.61299(16)$ & $2.75859(13)$ & $0.79161(20)$ & $0.89832(19)$ & $0.00094(9)$ & $-175.547(20)$ & 13 \\
\hline 35 & $0.61730(20)$ & $2.78036(14)$ & $0.79496(21)$ & $0.89754(21)$ & $0.00069(8)$ & $-170.194(21)$ & 18 \\
\hline 36 & $0.60169(10)$ & $2.50238(3)$ & $0.77717(10)$ & $0.90232(10)$ & $0.00118(10)$ & $-188.160(14)$ & 10 \\
\hline
\end{tabular}

$\mathrm{MAE}=$ mean absolute error, MaxAE $=$ maximum absolute error, $\mathrm{RMSE}=$ root mean square error, $\mathrm{R}=$ correlation coefficients, Bias = mean error, AIC = Akaike's information criterion and rank = numerical values in ranking method 
Errors of actual heights versus heights predicted in the fitting phase of the Cox $\mathrm{II}_{\mathrm{a}}$, Cox $\mathrm{II}_{\mathrm{b}}$ and Sharma \& Parton models are shown in Figure 3. There was no reason to reject the hypotheses of normality, homogeneity of variance and independence of residuals.
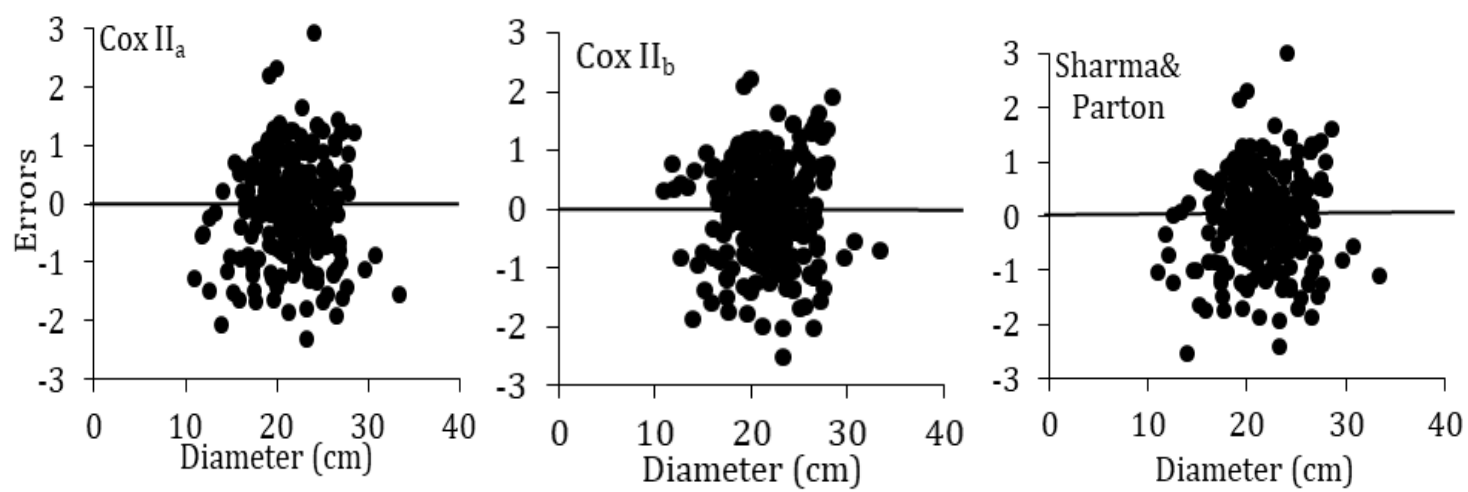

Figure 3. Errors actual heights versus predicted values in the fitting phase for the of Cox $\mathrm{II}_{a}$, Cox $I I_{b}$, Sharma \& Parton models

In general, it was found that the error amounts show an increase in successful models due to the increase in height values (Ahmadi et al., 2013; Özçelik and Çapar, 2014). The amount of error in our work did not increase, but decreased because this forest is plantation and trees have got similar height. It can be said that the variation with respect to the error distributions obtained with the generalized height-diameter models is relatively constant (from $-2 \mathrm{~m}$ to $+2 \mathrm{~m}$ ).

In this study, when it was decided whether a model is successful, it is required that the amount of error was small, and that it has a certain and constant variance in the errors were obtained. Tree height changed from 5.9 to $19.0 \mathrm{~m}$ in this study (in Table 2). In predicted of a tree height error about 2 meter was small. Cox IIa, Cox IIb, and Sharma \& Parton models were found successful in this respect.

In describing the diameter-height relationship, group 3 models including the stand age was more successful (Sánchez et al., 2003). However, results of group 2 models were found as the best models because of data were taken from artificial stands in this study.

Cox $\mathrm{II}_{\mathrm{a}}$, Cox $\mathrm{II}_{\mathrm{b}}$, and Sharma \& Parton models could offer a balance between the accuracy of model and sampling effort, because the value of stand age was not including for plantation in Group 2 models.

Observed heights versus the predicted heights in the cross-validation of this model are shown in Figure 4. The performance criterion to evaluate the behaviour of model was the determination coefficient of the straight line fitted between the observed and predicted heights. Figure 4 shows no tendency toward the overestimation or underestimation of height values.

For the tested models, the results obtained using the independent data set is given in Figure 4. The most similar results of Cox $\mathrm{II}_{\mathrm{a}}$, Cox $\mathrm{II}_{\mathrm{b}}$ and Sharma \& Parton models are shown in Figure 4. Relatively similar results were obtained for same models (Sánchez et al., 2003). The overlap ratio of the predicted height values with the measured height values does not increase as the height value increases. 

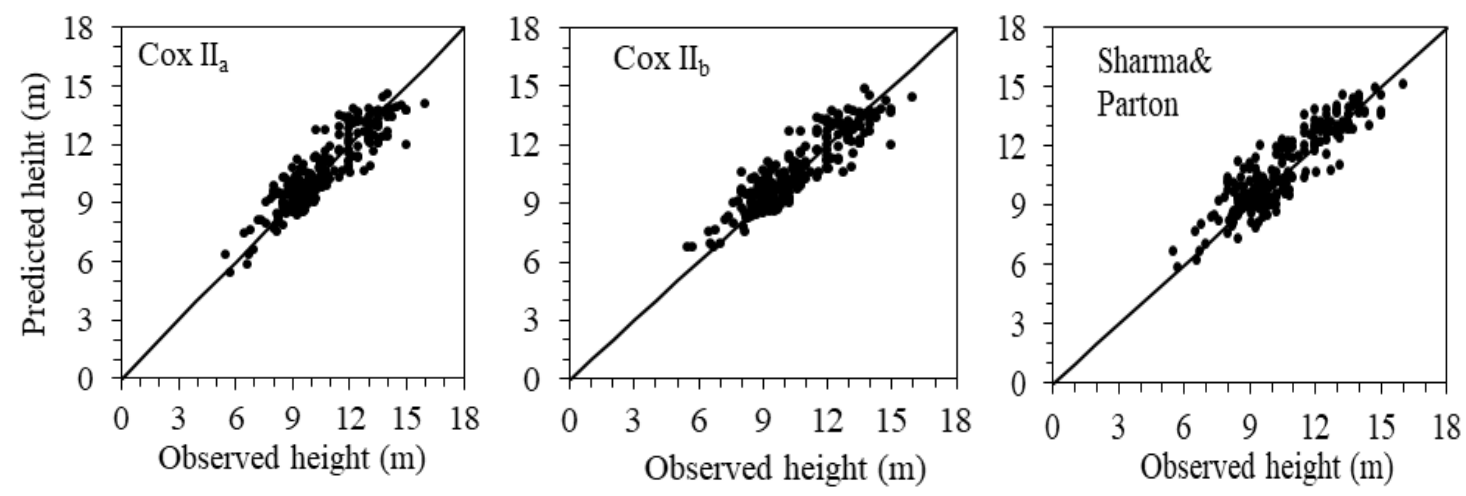

Figure 4. Observed heights versus predicted heights in the cross-validation for the Cox $I_{a}$, Cox $I I_{b}$ and Sharma \& Parton models

As can be seen from Table 5, the tested height-diameter models were not very different from the model development data.

Table 5. Criterion values for successful models with independent data set

\begin{tabular}{c|c|c|c|c|c|c|c}
\hline \multirow{2}{*}{$\begin{array}{c}\text { Model } \\
\text { no }\end{array}$} & \multicolumn{7}{|c}{ Performance criteria } \\
\cline { 2 - 8 } & MAE & MaxAE & RMSE & R & ME & AIC & Rank \\
\hline 24 & $0.68882(3)$ & $3.00290(5)$ & $0.87938(2)$ & $0.89799(3)$ & $-0.04821(1)$ & $-18.9777(2)$ & 2 \\
25 & $0.67832(1)$ & $2.99999(4)$ & $0.00113(3)$ & $0.89895(2)$ & $-0.05729(3)$ & $-12.4986(4)$ & 3 \\
27 & $0.71003(5)$ & $2.73425(2)$ & $0.91893(5)$ & $0.88752(5)$ & $-0.19489(5)$ & $-10.3754(5)$ & 5 \\
19 & $0.70434(4)$ & $2.66425(1)$ & $0.90841(4)$ & $0.88974(4)$ & $-0.19010(4)$ & $-15.1503(3)$ & 4 \\
22 & $0.68160(2)$ & $2.93107(3)$ & $0.87081(1)$ & $0.89963(1)$ & $-0.05696(2)$ & $-23.3373(1)$ & 1 \\
\hline
\end{tabular}

$\mathrm{MAE}=$ mean absolute error, MaxAE $=$ maximum absolute error, $\mathrm{RMSE}=$ root mean square error, $\mathrm{R}=$ correlation coefficients, Bias = mean error, AIC = Akaike's information criterion and rank = numerical values in ranking method

Finally, the most successful models were used for all sample plot data. Regression coefficients and statistics of these models are shown in Table 6. These parameters can use to estimate of diameter-height relationship for artificial brutian pine in southwestern Turkey.

Table 6. Regression coefficients and statistics obtained for the $d$-h models using the entire data set

\begin{tabular}{c|c|c|c|c|c|c|c|c|c}
\hline \multirow{2}{*}{$\begin{array}{c}\text { Model } \\
\text { no }\end{array}$} & \multicolumn{9}{|c}{ Parameters } \\
\cline { 2 - 10 } & $\mathbf{a}_{\mathbf{0}}$ & $\mathbf{a}_{\mathbf{1}}$ & $\mathbf{a}_{\mathbf{2}}$ & $\mathbf{a}_{\mathbf{3}}$ & $\mathbf{a}_{\mathbf{4}}$ & $\mathbf{a}_{\mathbf{5}}$ & $\mathbf{a}_{\mathbf{6}}$ & $\mathbf{a}_{\mathbf{7}}$ & $\mathbf{a}_{\mathbf{8}}$ \\
\hline 24 & 4.527680 & 1.217846 & -0.178316 & -9.800583 & -0.003507 & -0.000524 & - & - & - \\
25 & -122.56039 & 0.983721 & -0.711003 & 121.203832 & 0.002021 & $4.8 \times 10^{-51}$ & 42.055083 & 0.903834 & 0.812250 \\
27 & 1.426453 & 0.909989 & 0.028413 & -0.304526 & 1.710843 & - & - & - & - \\
19 & 8.405537 & 1.393674 & 0.322209 & -13.749983 & 1.970000 & - & - & - & - \\
22 & 0.431054 & -0.045442 & 0.957580 & 0.025728 & 0.006561 & - & - & - & - \\
\hline
\end{tabular}

$\mathrm{a}_{0}, \mathrm{a}_{1} \ldots=$ regression coefficients 


\section{Conclusions}

In this study, 36 height-diameter models were calibrated and tested for brutian pine plantations in southwestern Turkey. The best predictions of height were obtained by the Cox $\mathrm{II}_{\mathrm{a}}$ model, which used diameter $(\mathrm{d})$, quadratic mean diameter $\left(\mathrm{d}_{\mathrm{g}}\right)$, and stand mean height $\left(\mathrm{H}_{\mathrm{m}}\right)$ as independent variables. In this model, provides little effort has been made to model the height-diameter relationship in uneven-aged stands with generalized height-diameter functions. In addition, group 2 models should be used instead of group 3 models in the artificial stands.

The inclusion of stand mean height or of stand dominant height as an independent variable in the height-diameter equations seems to be necessary in order to achieve acceptable predictions. This requires the measurement of at least one sample of heights for the practical application of the equation. The inclusion of $d_{g}$ into the base heightdiameter model increased the accuracy of prediction.

As a result, examples of applications of the selected generalized height-diameter models to the forest management are presented, namely how to use it to complete missing information from forest inventory and also showing how such an equation can be incorporated in a stand-level decision support system that aims to optimize the forest management for the maximization of wood volume production in southwestern Turkey brutian pine stands.

\section{REFERENCES}

[1] Ademe, P., Del Rio, M., Canellas, I. (2008): A mixed nonlinear height-diameter model for hyrenean oak (Querqus pyrenaica Willd.). - For. Ecol. Manage. 256(1-2): 88-98.

[2] Ahmadi, K., Alavi, S. J., Kouchaksaraei, M. T., Aestern, W. (2013): Non-linear heightdiameter model for oriental beech (Fagus orientalis Lipsky) in the Hyrcanian forests. Iran. Biotechnol. Agron. Soc. Environ. 17: 431-440.

[3] Amateis, R. L., Burkhart, H. E., Zhang, S. (1995): TRULOB: Tree Register Updating for Loblolly Pine (An Individual Tree Growth and Yield Model for Managed Loblolly Pine Plantations). Coop. Rep. 83. - Virginia Polytechnic. Institute and State University, Loblolly Pine Growth and Yield Cooperative, Blacksburg, VA, USA.

[4] Anonymous (2015): Forest Resources. - Directorate of Forests, Ankara, Turkey.

[5] Bennett, F. A., Clutter, J. L. (1968): Multiple-Product Yield Estimates for Unthinned Slash Pine Plantations-Pulpwood, Sawtimber, Gum. USDA For. Serv. Res. Pap. SE-35. Southeast. Forest Exp. Stn., Asheville, NC.

[6] Budhathoki, C. B., Lynch, T. B., Guldin, J. M. (2008): A mixed-effects model for dbhheight relationship of shortleaf pine (Pinus echinata Mill.). - South. J. Appl. For. 32: 511 .

[7] Burkhart, H. E., Strub, M. R. (1974): A Model for Simulation of Planted Loblolly Pine Stands. - In: Fries, J. (ed.) Growth Models for Tree and Stand Simulation. Research Note 30, pp.128-135, Royal College of Forestry, Stockholm, Sweden.

[8] Cañadas, N., García, C., Montero, G. (1999): Relación altura-diámetro para Pinus pinea L. en el Sistema Central. - Congreso de Ordenación y Gestión Sostenible de Montes, Santiago de Compostela, 4-9 octubre. Tomo I, pp. 139-153.

[9] Castedo Dorado, F., Ruiz, A. D., Álvarez González, J. G. (2001): Modelización de la relación altura-diámetro para Pinus pinaster Ait. en Galicia mediante la función de densidad bivariante SBB. - Investigación Agraria, Sistemas y Recursos Forestales 10: $111-126$. 
[10] Castedo Dorado, F., Dieguez Aranda, U., Barrio Anta, M., Sanchez Rodriguez, M., Gadow, K. (2006): A generalized height-diameter model including random components for radiata pine plantations in Northwestern Spain. - For. Ecol. Manage. 229: 202-213.

[11] Çatal, Y. (2012): Height-diameter model for black locust, Anatolian black pine and Taurus cedar tree species in Lakes Region. - SDU J. Faculty For. 13: 92-96.

[12] Clutter, J. L., Allison, B. J. (1974): A Growth and Yield Model for Pinus radiata in New Zealand. In: Fries, J. (ed.) Growth Models for Tree and Stand Simulation, pp. 136-160. Research Note 30. - Royal College of Forestry, Stockholm, Sweden.

[13] Colbert, K. C., Larsen, D. R., Lootens, J. R. (2002): Height-diameter equations for thirteen mid-western bottomland hardwood species. - North. J. App. For. 19: 171-176.

[14] Cox, F. (1994): Modelos parametrizados de altura. Informe de convenio de investigación interempresas. - INFORA, Santiago.

[15] Curtis, R. O. (1967): Height-diameter and height-diameter-age equations for secondgrowth Douglas-fir. - For. Sci. 13: 365-375.

[16] Diamantopoulou, M. J., Özçelik, R. (2012): Evaluation of different modelling approaches for total tree-height estimation in Mediterranean region of Turkey. - Forest Systems 21: 383-397.

[17] Gaffrey, D. (1988): Forstamts-und bestandesindividuelles Sortimentierungsprogramm als Mittel zur Planung, Aushaltung und Simulation. - Diplomarbeit Forstliche Fakultät, Universität Göttingen, Germany.

[18] Harrison, W. C., Burk, T. E., Beck, D. E. (1986): Individual tree basal area increment and total height equations for Appalachian mixed hardwoods after thinning. - South. J. Appl. For. 10: 99-104.

[19] Huang, S., Price, D., Titus, S. J. (2000): Development of ecoregion-based heightdiameter models for white spruce in boreal forests. - For. Ecol. Manage. 129: 125-141.

[20] Hui, G., Gadow, K. v. (1993): Zur Entwicklung von Einheitshöhenkurven am Beispiel der Baumart Cunninghamia lanceolata. - Allg. Forst. Lagdztg. 164: 218-220.

[21] Krisnawati, H., Wang, Y., Ades, P. K. (2010): Generalized height-diameter model for Acacia mangium Willd. plantations in South Sumatra. - J. For. Res. 7: 1-19.

[22] Larsen, D. R., Hann, D. W. (1987): Height-Diameter Equations for Seventeen Tree Species in Southwest Oregon. Research Paper No 49. - Oregon State University Forest Research Laboratory, Corvallis, OR, USA.

[23] Lei, Y., Parresol, B. R. (2001): Remarks on Height-Diameter Modelling. Research Note SRS-10. - USDA Forest Service, Southern Research Station, Asheville, NC, USA.

[24] Lenhart, J. D. (1968): Yield of Old-Field Loblolly Pine Plantations in the Georgia Piedmont. - Ph. D. Thesis, Univ. Ga., Athens, Greece.

[25] Lootens, J. R., Larsen, D. R., Shifley, S. R. (2007): Height-diameter equations for 12 upland species in the Missouri Ozark Highlands. - North. J. Appl. For. 24: 149-152.

[26] López Sánchez, C. A., Varela, J. G., Catedo Dorado, F., Alboreca, A. R., Soalleiro, R. R., Álvarez González, J. G., Rodríguez, F. S. (2003): A height-diameter model for Pinus radiata D. Don in Galicia (Northwest Spain). - Ann. For. Sci. 60: 237-245.

[27] Mirkovich, J. L. (1958): Normale visinske krive za chrast kitnak i bukvu v NR Srbiji. Glasnik sumarskog fakulteta 13, Zagreb.

[28] Misir, N. (2010): Generalized height-diameter models for Populus tremula L. stands. Afr. J. Bio. 92: 4348-4355.

[29] Mønness, E. N. (1982): Diameter distributions and height curves in evenaged stands of Pinus sylvestris L. Medd. No. - Inst. Skogforsk 36: 1-43.

[30] Özçelik, R., Çapar, C. (2014): Developing generalized height-diameter models for natural Brutian pine stands in Antalya district. - SDU J. Faculty For. 15: 44-52.

[31] Pascoa, F. (1987): Estructura, crecimento e produçao em povoamentos de pinheiro bravo. Um modelo de simulaçao. - Ph.D. Thesis, Universidade Técnica de Lisboa, Lisbon, Portugal. 
[32] Peng, C. (1999): Nonlinear Height-Diameter Models for Nine Tree Species in Ontario Boreal Forests. Forest Research Report No. 155. - Ontario Forest Research Institute, Ontario, Canada.

[33] Pienaar, L. V., Harrison, W. M., Reheney, J. W. (1990): PMRC Yield Prediction System for Slash Pine Plantations in the Atlantic Coast Flatwoods. - PRMC Technical Report 1990-3, Athens, Greece.

[34] Prodan, M. (1968): Forest Biometrics. - Pergamon Press, Oxford, UK.

[35] Richards, F. J. (1959): A flexible growth function for empirical use. - J. Exp. Biol. 10: 290-300.

[36] Sanchez, C. A. L., Varela, J. G., Dorado, F. C., Alboreca, A. R., Soalleiro, R. R., Gonzalez, J. G. A., Rodriguez, F. S. (2003): A height-diameter model for Pinus radiata D. Don in Galicia (North-west Spain). - Ann. For. Sci. 60: 237-245.

[37] Schröder, J., Álvarez González, J. G. (2001): Developing a generalized diameter-height model for maritime pine in Northwestern Spain. - Forstwissenschaftliches Centralblatt 120: $18-23$.

[38] Sharma, M., Parton, J. (2007): Height-diameter equations for boreal tree species in Ontario using a mixed effects modelling approach. - For. Ecol. Manage. 249: 187-198.

[39] Sharma, M., Zhang, S. Y. (2004): Height-diameter models using stand characteristics for Pinus banksiana and Picea mariana. - Scan. J. For. Res. 19: 442-451.

[40] Sloboda, V. B., Gaffrey, D., Matsumura, N. (1993): Regionale und lokale Systeme von Höhenkurven für gleichaltrige Waldbestände. - Allg. Forst. Jagdztg. 164: 225-228.

[41] Soares, P., Tomé, M. (2002): Height-diameter model equation for first rotation eucalypt plantations in Portugal. - For. Ecol. Manage. 166: 99-109.

[42] Sönmez, T. (2008): Generalized height-diameter models for Picea orientalis L. - J. Environ. Biol. 30: 767-772.

[43] Temesgen, H., Gadow, K. V. (2004): Generalized height-diameter models-an application for major tree species in complex stands of interior British Columbia. - Eur. J. Forest Res. 123: 45-51.

[44] Temesgen, H., Zhang, C. H, Zhao, X. H. (2014): Modelling tree height-diameter relationships in multi-species and multi-layered forests: A large observational study from Northeast China. - For. Ecol. Manage. 316: 78-89.

[45] Tomé, M. 1989. Modelação do crescimento da árvore individual em povoamentos de Eucalyptus globulus Labill. (1'atrotação) na região centro de Portugal. - Ph.D. Thesis, Instituto Superior de Agronomía, Universidade Técnica de Lisboa, Lisbon, Portugal.

[46] Usta, H. Z. (1991): A Study on the Yield of Pinus brutia Ten. Plantations. - Turkish Forest Research Institute Publications, Ankara, Turkey.

[47] Weiskittel, A. R., Hann, D. W., Kershaw J. A., Vanclay J. K. (2011): Forest Growth and Yield Modeling. - Wiley-Blackwell Press, Chichester, UK.

[48] Wykoff, W. R., Crookston, C. L., Stage, A. R. (1982): User's Guide to the Stand Prognosis Model. General Technical Report. INT-133. - USDA Forest Service, Utah, USA. 